\title{
Nedostatek kvalifikovaných učitelů nelze řešit rezignací na kvalifikaci
}

Úplné vysokoškolské učitelské vzdělání bylo v ČR jako tehdy v jedné z mála zemí uzákoněno již v roce 1946. Jednalo se o krok, který dlouhá desetiletí požadovali nejen učitelé, ale i pedagogický výzkum a nakonec i politici. V roce 1964 se pak pedagogické fakulty staly i organizačně součástí univerzit. Spolu s absolventy tzv. odborných fakult prripravujících učitele tak všichni učitelé na základních a středních školách mají mít úplné vysokoškolské vzdělání. Je to podmínka nutná, i když nikoli postačující pro kvalitu školního vzdělávání. Jedním z cílù bylo posílit status a prestiž učitelství ve společnosti, přibližit ho $\mathrm{v}$ některých parametrech $\mathrm{k}$ uznávaným profesím, jako jsou lékaři nebo právníci. Srovnání je na místě, protože tzv. pravé či plné profese jsou ty, které se zabývají klíčovými potřebami společnosti, jejichž naplnění nelze zajistit jen nadšením a nápodobou zkušenějších. Mezi tyto potřeby se tradičně řadí např. zdraví, nedestruktivní uspořádání vztahů mezi lidmi a k nim přibylo i zajišstění mezigeneračního přenosu a soudržnosti společnosti prostřednictvím vzdělávání.

Dlouhá doba speciálního výcviku a soubor profesních, expertních znalostí a dovedností jsou považovány za klíčové znaky skutečných profesí, které odlišu- jí profesionály od „poučených“ amatérů a laiků. Důraz na pojetí učitelství jako na činnost založenou na hlubokých profesních znalostech a porozumění tak stojí v kontrastu $s$ intuitivním učitelstvím, pedagogickým kutilstvím založeným na tzv. folk pedagogy, vycházející z dojmů, nezdůvodněných názorů, subjektivních představ a př́stupů pokus-omyl.

Zvyšování kvality/profesionality učitelů a profesionalizace prrípravného učitelského vzdělávání jsou $\mathrm{v}$ posledních desetiletích jednou $\mathrm{z}$ klíčových priorit vzdělávací politiky ve vyspělých zemích. Jsou celosvětově považovány za klíčový nástroj vzdělávacích reforem, za podmínku úspěchu v jejich implementaci. Po roce 1989 se u nás otevřel prostor pro komplexní proměny $\mathrm{v}$ intencích mezinárodních trendů i v této oblasti. $S$ výjimkou vývoje $\mathrm{v}$ devadesátých letech však nebyly př́ležitosti pro podporu profesionalizace učitelství českou vzdělávací politikou využity. Naopak - jako evergreen ze strany vzdělávací politiky a decizní sféry se opakovaly snahy o snižování požadavků na kvalifikaci učitelů. Tyto kroky vyvolaly diskusi s názory typu, že přece stačí mít rád děti a na škole najít zkušeného mistra, který $\mathrm{v}$ adeptovi učitelství ten oheň pro učitelství zapálí (diskuse kolem 
Pithovy koncepce základní školy v letech 1992-1994).

Variací podobného podceňování vysokoškolského učitelského vzdělání byly po roce 2001 pokusy redukovat učitelské studium na bakalářské na základě laické představy: „čím mladší žáky vyučujete, tím méně toho potřebujete znát“. Některé legislativní návrhy se podařilo odvrátit (např. návrh novely zákona z roku 2007 předsedy školského výboru Parlamentu ČR W. Bartoše umožňující působení středoškolsky vzdělaných učitelů na základních školách jako plně kvalifikovaných), jiné bohužel prošly (novely z roku 2006 a 2011). Tyto novely lze považovat za jistou rezignaci vzdělávací politiky na kvalitu učitelů, nebot zmírňují kvalifikační požadavky u učitelů starších 50 let a požadavky na kvalifikovanost učitelů jednotlivých stupňů škol.

Diskuse ve společných pracovních skupinách Akreditační komise vlády ČR také řešily otázku, zda všichni učitelé potřebují tak vysoké vzdělávání po tak dlouhou dobu. Opakované souboje se vedly o to, zda je oborová didaktika vůbec věda a jestli nestačí znát především obor. A zda pedagogické a psychologické prrípravy není prŕliš mnoho. Výsledkem byly spory o podíl praxe studentů učitelství na školách a návrhy na omezení „neužitečné“ teorie.

Podobně byl po roce 2010 ve hře evergreen „více praxe, méně teorie“, který tentokrát nevyústil jen $\mathrm{v}$ posilování praxe během studia na vysoké škole, ale také v požadavek „odborníci z praxe do škol“. Větší podíl kvalitně reflektované praxe bě- hem počáteční učitelské přípravy je samozřejmě žádoucí. Bez ní poznatky oborové, ale i didaktické nebo psychologické šustí papírem. Požadavek přiblížit školy praxi a nedostatek učitelů odborných předmětů na středních odborných školách a učilištích vedly $\mathrm{k}$ výjimkám. Novelou zákona v roce 2014 tak bylo umožněno působit zejména ve středním školství odborníkům z praxe - ovšem jako nekvalifikovaným vyučujícím odborných předmětů. Odborníci z praxe tedy do škol mohou již dnes.

Podobně již dnes existuje zákonná vstř́cnost vůči nekvalifikovaným pracovníkům i na základních školách, aby mohli vyučovat všeobecně vzdělávací předměty. Ti měli od roku 2004 dvakrát pět let na doplnění učitelské kvalifikace, resp. na zahájení studia. Ze škol vždycky zaznívaly dva argumenty pro odstranění požadavku absolvování učitelského studia u těchto osob. Jeden byl zcela pragmatický a logický: Co má ředitel školy dělat, když opakovaně nemůže sehnat kvalifikovaného (natož aprobovaného) učitele? Druhý byl skrytě hodnotící a neuvědomovaně podřezával větev kvalitě vzdělávání a prestiži učitelství: Nekvalifikovaný působí na škole třeba pět deset let a jde mu to. Proč ho nutit, aby měl formální „glejt“, když ta pravá kvalita a učitelská moudrost se stejně nabývá hlavně děláním profese? Tak se postupně posilovalo logicky chybné přesvědčení, že učitelské studium je u každého „jen pro papír“ a vlastně nepředstavuje žádný přínos.

Drtivá většina nekvalifikovaných pracovníků přitom studium zahájila. Ostatně i z posledních statistik ministerstva školství 
vyplývá, že na 2. stupni základních škol je zajištována výuka v 7 \% úvazků nekvalifikovanými a jen $2,4 \%$ vyučujících učitelské studium nezahájilo (na středních školách je nekvalifikovaných úvazků něco přes $5 \%$ a studium dosud nezahájilo 2,3\%). V absolutních číslech jde vlastně o cca 2000 učitelů ze zhruba 70000 vyučujících na těchto stupních škol. Problém, který samozřejmě existuje, je tedy regionální (v Karlovarském kraji je podíl nekvalifikovaných úvazků téměr jedna pětina a kvalifikaci si nedoplňuje téměr $8 \%$ vyučujících) nebo aprobační (chybějí zejména učitelé fyziky, matematiky, informatiky, někde i cizích jazyků). $\mathrm{V}$ osmi krajích jde o zlomky jednoho procenta nebo maximálně do $2 \%$ nekvalifikovaných.

$\mathrm{Na}$ tuto situaci zareagovalo MŠMT, vláda a posléze i poslanci schválením novely zákona, kterým se mění zákon č. 563/2004 Sb., o pedagogických pracovnících. Konkrétně jde o $\$ 9$ a odst. 1 : „Zaměstnanci, který je absolventem akreditovaného magisterského studijního programu, může ředitel školy písemně uznat předpoklad odborné kvalifikace učitele druhého stupně základní školy nebo učitele všeobecně-vzdělávacích předmětů střední školy za splněný na dobu nejdéle 3 let ode dne, kdy tuto pedagogickou činnost začal vykonávat."

Tato úprava vychází z údajně kritického plošného nedostatku kvalifikovaných učitelů, $\mathrm{z}$ deklarované potřeby zkvalitnit výuku ve školách odborníky z praxe a z představy o nutnosti dále posílit pravomoci ředitelů v personální oblasti. Na regionální a vysoce pravděpodobně dočasný nedostatek kvalifikovaných učitelů $\mathbf{v}$ některých aprobacích totiž reaguje příslušný paragraf tak, že udělování (darování) učitelské kvalifikace ředitelem školy není pojato jako časově omezená výjimka podmíněná alespoň prýbuzností oboru vzdělání nekvalifikovaného pracovníka $s$ vyučovacím předmětem. Domníváme se, že argumenty, z nichž vychází návrh novely, jsou nepřesné a zcela podceňují velké riziko, které by schválení novely přineslo.

Za prvé, jak jsme výše uvedli, nedostatek učitelů není plošný. Místo regionálně a aprobačně zacílených opatření navrhuje novela cestu plošného snížení kvalifikačního požadavku. Přitom objektivní údaje z matriky MŠMT se liší od alarmistických údajů ze „šetření založených na ad hoc informacích od ředitelů škol, kterými podporovatelé novely argumentovali. Katastrofický obraz nedostatku učitelů vychází z lineárního prodloužení nedostatku učitelů v letech 2014-2018, předpokládaných odchodů do důchodu a snižujícího se procenta nastupujících absolventů učitelského studia. Ignoruje pokles demografické křivky žáků ve věku základní školní docházky, zvyšování platů učitelů i pravděpodobné návraty absolventů učitelského studia do škol v důsledku po-covidové situace na trhu práce. Rok 2021 se zdá být $\mathrm{v}$ těchto ukazatelích bodem obratu. Různé modely situace např. $v$ roce 2024-2025 však nebyly předloženy.

Za druhé, jak jsme již uvedli, zkvalitnění výuky otevřením „odborníkům z praxe“ je vlamováním se do otevřených dveří. Navíc předpoklad, že půjde nutně 
o odborníky, je zcela nedoložený a je spíše zbožným přáním. Naproti tomu skutečný problém neaprobované výuky novela ještě prohlubuje. Nejprve je nutné uvést, že na 2. stupni ZŠ, který se nekvalifikovaným nově doširoka otevírá, se žádné odborné předměty nevyučují. Novela bez jakéhokoli zdůvodnění a analýzy dopadů na kvalitu vzdělávání rozšiřuje možnost nekvalifikovaně vyučovat i na 2 . stupeň $Z S ̌$ všeobecně-vzdělávací předměty, např. matematiku nebo český jazyk. A ještě více než dnes rozvolňuje vazbu na předmět odbornosti (aprobaci). Vysokoškolský absolvent jakéhokoli oboru totiž bude moci vyučovat jakýkoli vyučovací předmět. Dikce novely nezabraňuje možnosti, aby např. odborník na elektrotechniku učil český jazyk na 2. stupni ZŠ a absolvent českého jazyka biologii. Minimálně ze systémového hlediska lze tedy o zkvalitnění výuky důvodně pochybovat.

Znění novely navíc ani nepožaduje, aby pedagogicky nekvalifikovaný učitel současně se zahájením pedagogického působení zahájil učitelské studium (pedagogické minimum). $V$ současné dikci zákona je alespoň požadovaná podmínka, že si pedagogické vzdělání doplní např́klad v 250hodinovém doplňujícím pedagogickém studiu (DPS). Statistiky přitom již dnes dokládají, že třetina nově kvalifikovaných učitelů - potenciálních odborníků s jiným vzděláním - absolvovala právě DPS.

Za třetí, z hlediska garance kvality celého systému vzdělávání nelze akceptovat ujištování, že jejímu př́ípadnému ohrožení nekvalifikovaným učitelem zabrání „rozumní“ ředitelé škol. Vnímáme nároč- nou práci a obtížnou situaci ředitelů škol. Naše kritika de-kvalifikační a de-profesionalizační novely zákona však nijak nezpochybňuje velkou odpovědnost a kompetentnost ředitele rozhodovat o tom, jací učitelé a jak v jeho škole působí. Není to však odpovědnost výlučná, jak se mnohdy mylně argumentuje. Tu odpovědnost mají na různé úrovni stát, zřizovatelé i vzdělavatelé učitelů. Vždyt tam, kde jde o veřejný zájem (a nikoli o zájem privátní, rodičovský, ředitelský nebo lokální), vždy platí, že pravidla se nastavují z hlediska celku. Nechceme znovu připomínat $\mathrm{v}$ úvodu námi prripomenuté srovnání s uznávanými profesemi lékaře nebo právníka. Zajištění respektu $\mathrm{k}$ veřejnému zájmu lze demonstrovat na banálním příkladu. Zákon přikazuje mít řidičský průkaz založený na absolvování často kritizované teorie (pravidla silničního provozu) a leckdy nedostatečné praxi. Přitom víme o mnoha „řidičích“, kteří velmi slušně řídí i bez toho „papíru“. Dokonce jich možná ještě před získáním průkazu nebude málo. Proč nikoho nenapadne předložit novelu silničního zákona, když nám chybějí řidiči autobusů nebo dálkové dopravy?

Symbolicky ovšem ohrožuje učitelství jako profesi bezprecedentní fakt, že ředitel školy jakýmsi performativním aktem udělí nekvalifikovanému vysokoškolákovi učitelskou kvalifikaci. Údajně na tři roky, ačkoli dikce novely nijak nezabraňuje řetězení těchto tř́letých období. Máme spoléhat na morálku ředitelů a zřizovatelů? Ve všech vyspělých zemích uděluje profesní kvalifikaci stát, nikoli ředitel školy. U uznávaných profesí ani nelze 
uvažovat o jiném potvrzení kvalifikace. Z mezinárodních srovnání a doporučení (např. OECD 2020: Education at a Glance nebo Eurydice 2018: Teaching Careers in Europe: Access, Progression and Support) jasně vyplývá, že kromě Estonska bychom byli jedinou zemí, v níž je možné získat učitelskou kvalifikaci rozhodnutím ředitele školy. $\mathrm{Na}$ rozdíl od všech ostatních zemí, i těch, v nichž jsou problémy s nedostatkem kvalifikovaných učitelů větší než u nás. Opravdu chceme být v tomto smyslu „best in“?

Novela ponechává řediteli naprostou volnost pro zaměstnání „mnohem schopnějšího bez kvalifikace“. Když se řediteli prihlásí absolvent učitelského studia, nic ho nebude nutit, aby prezkoumal, zda je „nekvalifikovaně kvalifikovaný “ skutečně schopnější. Oba budou v dané chvíli kvalifikovaní - jeden studiem, druhý „ředitelsky“.

Předpoklad, že úplné vysokoškolské vzdělání učitelů (nejen z pedagogických fakult, jak se mylně opakuje) tímto krokem nebude znehodnoceno, je mylný. Ve sborovnách budou vedle sebe ti, kteří absolvovali léta speciálně zaměřeného vzdělávání, náslechy, rozbory praxe aj., a vedle nich podle novely stejně kvalifikovaní - podpisem ředitele. Již nyní lze z reakcí učitelů vyčíst, že tuto situaci vnímají jako degradaci vlastního vzdělání. To, co bylo dříve výjimkou (pedagog bez učitelského vzdělání a praxe s dětmi), se má stát normou.

Neplatí tedy, že novela ,jen“ kodifikuje běžný stav na školách, zkvalitní výuku odborníky z praxe a uleví ředitelům. Rizika rozpadu systému prípravy na regulovanou profesi jsou ve světle výzkumných důkazů o vztahu kvalifikace učitelů a výsledků žáků zřejmá. Rezignaci na kvalifikaci učitelů považujeme za hazard $s$ kvalitou vzdělávání v ČR. Novela, resp. její $₫ 99$, není jen regresem vzhledem $\mathrm{k}$ naší tradici, ale je zcela $v$ protikladu $s$ vývojovými trendy ve vyspělých zemích. Zatímco my jdeme cestou de-profesionalizace učitelství (jejímž vyjádřením je $\$ 9$ a novely), vyspělý svět jde opačným směrem. A to zvyšováním nároků na profesionalitu učitelů, na kvalitu jejich vzdělávání - napřr. roste délka studia, $\mathrm{v}$ řadě vyspělých zemí mají vysokoškolské univerzitní vzdělání i učitelky mateřských škol.

Namísto krátkozrakých a zkratkovitých řešení problémů by vzdělávací politika měla promýšlet a navrhovat opatření z hlediska dlouhodobějších perspektiv. Namísto snižování požadavků na kvalifikaci a profesionalitu učitelů by měla naopak formulovat vysoký, ambiciózní standard kvality učitelské profese podložený výzkumem včetně vytváření podmínek pro zajištování kvality a systémové podpory učitelů v jejich celoživotním profesním růstu.

\section{SHRNUTí PROBLÉMŮ}

- V České republice (podobně jako v jiných zemích) vyučuje žáky určitá část učitelů, kteří nemají aprobaci pro daný vyučovací předmět (ale mají vystudované učitelství) anebo nemají učitelskou kvalifikaci vůbec. Je to však problém regionální, nikoli masový a je vázán jen na určité vyučovací předměty. 
- U nekvalifikovaných učitelů ( $\mathrm{tj}$. těch, kteří nevystudovali učitelství, a přesto pomáhají na některých školách řešit nedostatek kvalifikovaných učitelů) se už vyzkoušelo, že si mohou doplnit legislativně vyžadovanou kvalifikaci a není třeba měnit zákon, což tvůrci novely nevzali v úvahu.

- Učitelství patří mezi tzv. regulované profese a regulačním orgánem je MŠMT. V ČR se zájemci o učitelství dosud připravovali bud' studiem na fakultách vysokých škol ${ }^{1} \mathrm{v}$ rámci specializovaných učitelských studijních programů, nebo si doplňovali chybějící pedagogické vzdělání v tzv. doplňujícím pedagogickém studiu. K těmto dvěma skupinám kvalifikovaných učitelů přidává novela třetí skupinu tzv. ředitelsky kvalifikovaných - nekvalifikovaní pracovníci získají učitelskou kvalifikaci rozhodnutím ředitele jedné konkrétní školy. Absolventi vysokoškolského vzdělání jakéhokoli zaměření pak mohou vyučovat na základních a středních školách jakýkoli vyučovací př̀edmět.
- Učitelská př́íprava má - podle dosud platné legislativy ${ }^{2}$ - čtyři hlavní složky: učitelskou propedeutiku (pedagogika, psychologie atd.), oborové didaktiky, oborovou složku (zpravidla dva aprobační obory) a pedagogickou praxi. Ti, kdož nastoupí (podle znění novely) do škol, budou splňovat ze čtyř složek pouze jednu - vystudovaný obor. Bude jim chybět učitelská propedeutika, oborové didaktiky a pedagogická praxe. Pokud však využijí volnosti novely zákona a budou vyučovat předmět, který na vysoké škole nevystudovali, nebudou kvalifikovaní ani pro oborovou složku, což autorům novely zřejmě nevadí.

- Rezignace na kvalifikaci učitelů a de-profesionalizace učitelství (vyjádřené paragrafem $\$ 9$ a odst. 1 novely zákona) vedou český vzdělávací systém opačným směrem, než se vydaly vyspělé země. Ty naopak posilují profesionalitu svých učitelů. „Česká cesta“ bude mít negativní dopady nejenom na samotnou učitelskou profesi a učitelské sbory, ale hlavně na žáky a kvalitu jejich vzdělání.

PhDr. Martin Chvál, Ph.D., doc. PhDr. Tomás Kasper, Ph.D., PhDr. Dalibor Kučera, Ph.D., doc. PhDr. PaedDr. Anna Kucharská, Ph.D., prof. PhDr. Jiř̌ Mareš, CSc., prof. PhDr. Karel Rýdl, CSc., prof. PhDr. Vladimira Spilková, CSc., prof. PaedDr. Iva Stuchliková, CSc., prof. PhDr. Stanislav Štech, CSc., PhDr. Klára Uličná, Ph.D.

\footnotetext{
${ }^{1}$ Nejde pouze - jak se mylně traduje - o fakulty pedagogické, ale také o fakulty filozofické, př́rodovědecké, ekonomické, teologické, sportovní, technické apod.

${ }^{2}$ Rámcové požadavky MSMT-21271/2017-5.
} 